\title{
Reporting Tragic Events Using Mobile Phones: Citizenship Photojournalism in Critical Tragedy in Nigeria?
}

\author{
Patrick E. Okon, Tolulope Kayode-Adedeji, and Lanre Amodu \\ Covenant University, Mass Communication Department, Ota 234, Nigeria \\ Email: patrick.okon@ covenantuniversity.edu.ng; kehinde.kayode-adedeji@covenantuniversity.edu.ng; \\ lanre.amodu@covenantuniversity.edu.ng
}

\begin{abstract}
The paper considers the reportage of tragic events in Nigeria by ordinary citizens, using mobile phones and other digital devices. The focus is on the moral agency of citizenphotojournalists, the dilemma inherent in the exercise of that agency, the technological structure that enable/impede such agency, and the resulting ethical tragedy for citizenship photojournalism. The questions addressed are: On what cultural activity rests the moral agency of citizen-photojournalists in Nigeria? How does mobile technology enable or impede the exercise of that moral agency? How do the citizens who own and use mobile technology reconcile the duty of care for victims of tragic public incidences and the immediate concern to represent events in ways that are fresh and immediate? Does the failure to provide care for victims of tragic events in the course of citizenship reporting constitute an ethical tragedy for the practice? Two cases of citizenship visual reporting in relation to tragic events in Lagos-Nigeria are studied (the Badagry boy's saga and the Odunfa-Okepopo conflict). Mixed methods approach (content analysis and oral interview) is used in a qualitative way to generate data. The theory of media witnessing is used to ground the study. Findings show that in each case of citizen visual reporting, there is a serious negligence of the requisite duty of care towards victims of tragic public situations, resulting in an unconscious or deliberate undermining of some of the core values of citizenship journalism. Such negligence is also a revelation of the hypocrisy underlying the practice of citizenship photojournalism. Beyond social regulatory needs, the paper recommends careful balancing in practice responsibilities.
\end{abstract}

Index Terms - Care, witnessing, mediation, dilemma, tragedy, citizenship reportage, mobile technology

\section{INTRODUCTION}

On November 16, 2016, some videos went viral on some social media of a young boy, beaten to a state of unconsciousness and set aflame at Alafia-Badagry, Lagos State, Nigeria. From the voices heard in the video, it was alleged that the boy stole a mobile phone from a passerby (some versions of the online reports alleged he stole garri from a local business shop). It was also alleged that the boy wanted to stab with a knife the owner of the mobile phone before he was apprehended by the local people, beaten and burnt to death in public view. This

Manuscript received July 12, 2018; revised March 7, 2019. doi:10.12720/jcm.14.4.324-334 was purely a matter of jungle justice which is seriously frowned at by the Nigerian legal system. However, the most disturbing aspect of the event was the liberty and conscienceless manner with which one of the onlookers videoed and photographed this barbaric act, perhaps for the purpose of witnessing to the event through online media.

The second scenario is the case of Odunfa versus Okepopo street fight which video also made waves on social media. It is the case of an annual Adakeja masquerade festival that turned bloody in the Adeniji Adele area of Lagos Island on October 19, 2016. The supporters of the masquerader clashed with some youths loyal to the local traditional ruler. A teenager, Charles Igbinovia, was run down, mulled over, and butchered by the supporters of the masquerader. One other man was also killed. Several others were reportedly wounded. By October 20, videos of some scenes of the battle, particularly the butchering of the young boy, flooded social media. Here, too, the most amazing aspect of the event was the presence, perhaps, of alone citizen spontaneously photographing and videoing the tragic events, using a mobile device, in order to bear witness to the conflict.

In both cases, while the visual images are significant as each has a story to tell, the contradictions inherent in their very productions problematizes the duty of care the practice requires towards victims of tragic events. The interrogation of this paper is not on the realistic nature of these footages, but more specifically on the social responsibility inherent in and the moral dilemma sometimes faced by onlookers, who also double as citizen reporters, in the exercise of visual witnessing.

\section{A NARRATIVE OF WITNESSING AND TESTIMONY}

Though there is now a multiplicity of definitions of the term 'witnessing', in most recent times the concept "has emerged as a way to describe how digital technologies are transforming the capacity to bear witness, encouraging a number of productive lines of investigation" [1].

Frosh and Pinchevski [2:20-21] admit that media witnessing simply captures something that is central, not only to the practices of contemporary media, but also 
significant to the aesthetics, ethics, and politics of representation. The authors argue that media witnessing is principally concerned with "the systematic and ongoing reporting of the experiences and realities of distant others to mass audiences" [2:1]. It implies the simultaneous configuration and conflation of three distinctive things: "the appearance of witnesses in media reports; the possibility of media themselves bearing witness; and the positioning of media audiences as witnesses to depicted events" [2:1]. For example, the visual reportage of the Badagry boy's saga and the Odunfa-Okepopo conflict may be seen to, simultaneously, depict witnesses to the events, bear witness to those events, and turn bystanders into witnesses of the events

However, at the core of most cases of media witnessing is what Frosh and Pinchevski term as the "crisis of witnessing" [2:3] - whereby victims, because of forgetfulness or speechlessness resulting from the overwhelming nature of the experience, or the sudden death of the victims themselves, are unable to report directly about their traumatic experiences. In this case, the bystanders, convinced of the perpetrators' attempt to extinguish the internal witness of their victim(s), could build a discourse that bears out the traumatic processes in the form of documentary videos or photographs, so as to mediate on behalf of the victim(s). In this regard, the authors argue, the medium of video could be vital in documenting the personal memories of witnesses of traumatic events, so that what the perpetrators attempt to bury is given new visibility [2:4].

Frosh and Pinchevski's [2] study is vital to the understanding of the concern of this paper on a number of points: Firstly, the concept of 'witnessing', articulated by the authors, could be stretched to aid the understanding of a wide range of visual communication issues in relation to the representation of traumatic experiences through citizenship photojournalism in Lagos-Nigeria. Secondly, the word can enable us to see all forms of media practice (professional and amateurish) as a kind of testimony to crisis situations, enabled especially by changes in technologies (including cellphone-based cameras). Thirdly, 'media witnessing' offers, conceptually, a demonstration of the connection between 'embedded journalism' and 'citizen journalism', namely, the attempt by professional reporters and ordinary citizens to put an experience into a visual language for the benefit of those who were not there and for the purpose of mediation in favour of the victim(s) of that experience. Fourthly, 'witnessing' provides a useful conceptual framework for connecting the burden of care towards victims of atrocious events and the imperative of social responsibility contract exercised through visual reportage.

\section{Methodology OF StUdy}

The study drew on the benefits of 'mixed methods' (content analysis and oral interviews) used in a qualitative way. The dominant method was content analysis. The complementary method was oral interview. The latter was meant to enable the authors respond to some issues that could not be addressed through content analysis.

Four respondents in all were selected for oral interviews: Two were chosen from The Punch Newspapers - one a senior photojournalists (Abuja) and the other an acting news editor with The Sunday Punch (Lagos); the other two were senior academics (of the professorial ranks) from the University of Uyo (UNIYO) and the University of Lagos (LASU). About thirtyminutes telephone conversation was held with each interviewee in January 2018. Their views were recorded, transcribed and analysed.

The samples for content analysis were four different footages (two for each event), about the killing and setting aflame of the boy in Badagry as well as the Odunfa-Okepopo street conflict in Lagos Island. The primary foci were the manifest contents of the videos circulated online and their accompanying text commentaries. The focus of the videos analysis was on frequency measurement, rather than on intensity. The text commentaries were drawn from only one online source (https://www.youtube.com/watch?v=Jfgtuq8zatI\&t=90s). The measureable units were tied around predetermined thematic categories, such as news value, age value (only perpetrators), social status (only perpetrators), emotional moods (both victim and perpetrators), voice (both victim and perpetrators), presence of security, environment of perpetration, predetermined outcome (victim-related), presence of care, determination of perpetrators, and the mobile technology type. The conceptual units of analysis chosen were meant to address different issues in relation to the four sets of research questions proposed at the beginning of the paper.

Below is a representation of findings in tabular format and their frequency analysis (whereby $1=$ High; $2=$ Middle; 3 = Low; and Not applicable = complete absence):

\begin{tabular}{|l|l|l|l|l|l|l|l|}
\hline S/N & CATEGORIES & THEMES & $\begin{array}{l}\text { BADAGRY } \\
\left(1^{\text {st }} \text { Video }\right)\end{array}$ & $\begin{array}{l}\text { BADAGRY } \\
\left(2^{\text {nd }} \text { Video }\right)\end{array}$ & $\begin{array}{l}\text { LAGOS } \\
\text { FIGHT } \\
\left(1^{\text {st }} \text { Video }\right)\end{array}$ & $\begin{array}{l}\text { LAGOS } \\
\text { FIGHT } \\
\left(2^{\text {nd }} \text { Video }\right)\end{array}$ \\
\hline 1 & News Value & $\begin{array}{l}\text { Of News Value } \\
\text { Not of News Value }\end{array}$ & 1 & 3 & 1 & 1 & 1 \\
\hline 2 & Age Value & $25-35$ & 1 & 1 & 3 & 3 \\
& (Perpetrators) & $36-45$ & 2 & 2 & 2 & 2 \\
\hline 3 & Above listed & 3 & 3 & 3 & 3 & 3 \\
\hline
\end{tabular}




\begin{tabular}{|c|c|c|c|c|c|c|}
\hline & (Perpetrators) & $\begin{array}{l}\text { Middle class } \\
\text { Low class }\end{array}$ & $\begin{array}{l}2 \\
1 \\
\end{array}$ & $\begin{array}{l}2 \\
1 \\
\end{array}$ & $\begin{array}{l}2 \\
1 \\
\end{array}$ & $\begin{array}{l}2 \\
1 \\
\end{array}$ \\
\hline 4 & $\begin{array}{l}\text { Mood } \\
\text { (Perpetrators) }\end{array}$ & $\begin{array}{l}\text { Fulfilled } \\
\text { Angry } \\
\text { Sympathetic }\end{array}$ & $\begin{array}{l}3 \\
1 \\
3\end{array}$ & $\begin{array}{l}1 \\
3 \\
2\end{array}$ & $\begin{array}{l}3 \\
1 \\
3\end{array}$ & $\begin{array}{l}3 \\
1 \\
3\end{array}$ \\
\hline 5 & $\begin{array}{l}\text { Prominence of citizen } \\
\text { Witness }\end{array}$ & $\begin{array}{l}\text { Prominent } \\
\text { Not prominent } \\
\text { Lost in the crowd }\end{array}$ & $\begin{array}{l}1 \\
2 \\
3 \\
\end{array}$ & $\begin{array}{l}1 \\
2 \\
3 \\
\end{array}$ & $\begin{array}{l}1 \\
2 \\
3\end{array}$ & $\begin{array}{l}1 \\
2 \\
3 \\
\end{array}$ \\
\hline 6 & $\begin{array}{l}\text { Ethical Value of the } \\
\text { crime }\end{array}$ & $\begin{array}{l}\text { No Ethical value } \\
\text { Ethical Value }\end{array}$ & $\begin{array}{l}1 \\
3\end{array}$ & $\begin{array}{l}1 \\
3\end{array}$ & $\begin{array}{l}1 \\
3\end{array}$ & $\begin{array}{l}1 \\
3\end{array}$ \\
\hline 7 & $\begin{array}{l}\text { Presence of victim's } \\
\text { testimony }\end{array}$ & $\begin{array}{l}\text { No Evidence } \\
\text { Evidence }\end{array}$ & $\begin{array}{l}1 \\
3\end{array}$ & $\begin{array}{l}1 \\
3\end{array}$ & $\begin{array}{l}1 \\
3\end{array}$ & $\begin{array}{l}1 \\
3\end{array}$ \\
\hline 8 & Voice & $\begin{array}{l}\text { Victim's plea } \\
\text { Perpetrators assertions } \\
\text { Silence }\end{array}$ & $\begin{array}{l}2 \\
1 \\
3 \\
\end{array}$ & $\begin{array}{l}2 \\
1 \\
3 \\
\end{array}$ & $\begin{array}{l}2 \\
1 \\
3\end{array}$ & $\begin{array}{l}\text { Not } \\
\text { Applicable }\end{array}$ \\
\hline 9 & Security & $\begin{array}{l}\text { Security } \\
\text { No Security }\end{array}$ & $\begin{array}{l}3 \\
1\end{array}$ & $\begin{array}{l}3 \\
1\end{array}$ & $\begin{array}{l}3 \\
1\end{array}$ & $\begin{array}{l}3 \\
1\end{array}$ \\
\hline 10 & Environment & $\begin{array}{l}\text { Urban } \\
\text { Town } \\
\text { Local }\end{array}$ & $\begin{array}{l}3 \\
2 \\
1\end{array}$ & $\begin{array}{l}3 \\
2 \\
1\end{array}$ & $\begin{array}{l}3 \\
2 \\
1\end{array}$ & $\begin{array}{l}3 \\
2 \\
1\end{array}$ \\
\hline 11 & Outcome & $\begin{array}{l}\text { Rescue of Victim } \\
\text { Death of victim } \\
\text { Harm of Victim }\end{array}$ & $\begin{array}{l}3 \\
2 \\
1\end{array}$ & $\begin{array}{l}3 \\
2 \\
1\end{array}$ & $\begin{array}{l}3 \\
2 \\
1\end{array}$ & $\begin{array}{l}\text { Not } \\
\text { Applicable }\end{array}$ \\
\hline 12 & Care & $\begin{array}{l}\text { Presence of care } \\
\text { Lack of care }\end{array}$ & $\begin{array}{l}3 \\
1\end{array}$ & $\begin{array}{l}3 \\
1\end{array}$ & $\begin{array}{l}3 \\
1\end{array}$ & $\begin{array}{l}\text { Not } \\
\text { Applicable }\end{array}$ \\
\hline 13 & Determination & $\begin{array}{l}\text { To destroy the victim } \\
\text { To redeem the victim } \\
\text { To redeem the community }\end{array}$ & $\begin{array}{l}1 \\
3 \\
2 \\
\end{array}$ & $\begin{array}{l}1 \\
2 \\
1 \\
\end{array}$ & $\begin{array}{l}1 \\
3 \\
2 \\
\end{array}$ & $\begin{array}{l}1 \\
2 \\
3 \\
\end{array}$ \\
\hline 14 & Mobile Device Type & $\begin{array}{l}\text { Evident } \\
\text { Not Evident }\end{array}$ & $\begin{array}{l}3 \\
1 \\
\end{array}$ & $\begin{array}{l}3 \\
1 \\
\end{array}$ & $\begin{array}{l}3 \\
1 \\
\end{array}$ & $\begin{array}{l}3 \\
1 \\
\end{array}$ \\
\hline 15 & $\begin{array}{l}\text { Online } \\
\text { comments/Opinion }\end{array}$ & $\begin{array}{l}\text { Affirmation } \\
\text { Negation } \\
\text { Neutrality }\end{array}$ & $\begin{array}{l}3 \\
1 \\
2 \\
\end{array}$ & $\begin{array}{l}2 \\
1 \\
3 \\
\end{array}$ & $\begin{array}{l}\text { Not } \\
\text { applicable }\end{array}$ & $\begin{array}{l}\text { Not } \\
\text { applicable }\end{array}$ \\
\hline
\end{tabular}

\section{ANALYSIS AND INTERPRETATION OF DATA}

Here, we attempt to make sense of the data, using the four research questions as guides. Answers to some of the questions are footage-based; others are based on data from indepth interviews or both:

\section{A. The Moral Agency of Citizen Photojournalists}

The moral agency of citizen visual reporters and the cultural activity that defines and underlines that agency were tested by four elements, namely, the presence of citizen witness, the characteristics of the witnesses/perpetrators, the news value of the video reports, and the respect for ethical standards in the exercise of the moral agency of citizenship.

Evidence indicates a high prominence of citizen witnesses in the two sets of videos. Citizenship reporting or what Allan [1] describes as "accidental journalism" or "first-person reporting", has become a central and crucial aspect of our media and communication landscapes. As a special genre of the communication practice distinguishable from the mainstream, citizenship witnessing, in its diversified forms and formats, constitutes "the spontaneous actions of ordinary people compelled to adopt the role of news reporter in order to bear witness to human suffering" [3], [3:4], particularly during a time of crisis or disaster when they happen to be present on the scene.

This cultural practice has often been associated with the imperative of witnessing because of its orientation towards the provision of intervention to mediate in the sharp pull resulting from conflicts and atrocities. In all the visual cases, the citizen-photojournalists are part and parcel of the bystanders. They are personally present as eyewitnesses at the scenes of the crimes against their young victims.

Allan's [1] tripartite witnessing modalities (the activity of indifferent bystanders who are confronted with a sense of care as a necessary response to the plight represented before them; individuals suddenly caught up in an unexpected event and who are moved to document fleeting aspects of the events in order to share with others; and the citizens purposefully witnessing as activists to challenge injustice, reveal a humanitarian crisis, record grisly realities of conflict or even to expose a hidden abuse), however, reveals the complexity of responses possible in representing the different positioning of the witnesses who recorded the atrocities in Badagry and Lagos Island.

One of this paper's greatest challenges, however, is that of being able to state in explicit terms which of the modalities characterize our videographers of interest. As a result of this difficulty, this paper prefers to refer to these anonymous videographers as 'bystanderparticipants' or 'citizen-witnesses'. In this regard, Allan's warning that the modalities represented should be seen, not just as social contingencies, but as imagined modalities for the purpose of analytical clarity should be seen to apply in this context; that is, if we must avoid the 
problematic that could arise if these categories were to be understood too literally [1: 175].

Again, it must be noted that all the footages analysed were taken by the 'bystanders' at the spur of the moment. While in the Badagry case, the person recording stands almost shoulder-by-shoulder with the perpetrators, in the case of the Lagos Island fighting, the shooting is made from the first or second floor of a storey building. But in all the videos, the citizen witness has made himself or herself conspicuously absent from the shots. His or her presence is confirmed only by camera presence and activity.

The purposes for the generations of the footages are not explicit from the videos themselves. But circumstantial evidence (e.g. the utterances of the videographers, the perpetrators, and the readers' textual reactions) tend to suggest witnessing for the purpose of information, activism, and mediation as the principal objectives.

While the victims are by all standards minors (ages 15 and 18 years), the perpetrators are largely young adults (ages 25 and 35 years) whose intellectual grasps of sociocultural and legal realities would have been expected to be higher. The perpetrators are also largely of 'low' social status; only a limited number could be considered to be of 'middle class' category. How the perpetrators" "low" social class could impact on their understanding of the need of their immediate sociocultural environments and their ability to control the floods of emotions rising from within them in response to the perceived criminal offences of the victims is not explicit in the video, but could only be 'read' from their actions or inactions in the videos.

Also, visual evidence shows that the contents of all the videos have high news values. The contents are meant to tell stories and communicate information to the public. Reliance on Tulloch and Blood's [4] value specification could highlight other forces, outside news consideration, that could shape the integrity of these videos. For instance, there are their resourcefulness in demonstrating significant moments in history; their foregrounding of the dominant social ideology of a particular community; expressing the social conditions that possibly generated the events; underlining the kind of rhetoric that gave inspiration to its uprising; bearing witness to the wounds of atrocities; as well as the processes needed to attain liberation.

The ideological dimension, in particular, may be tied with the acceptability of the value of jungle justice as a sociocultural practice in righting wrongs in a local community in Nigeria. However, the communicative, modelling and reformative potentials of these footages could not be far removed from the effects of their emotive powers and their ability to expose, interpret and correct what ordinarily would have been hidden from public discourses and public policy decision-making processes. One other significant value is that these videos could be depended upon by mainstream and other alternative news establishments to develop story ideas and for activism against all forms of atrocious public engagements by young people.

Chouliaraki's [5] "visual politics of journalism" can also be extended to the understanding of certain issues about these visuals. The concept, according to the author, is crucial for thematizing visual images as "the symbolic definition(s) of world events", whereby these images function to make visible and render intelligible "places and people otherwise not available to us through immediate experience" [5: 520]. It is this symbolization role that also defines what is at stake in citizen visual reflexivity; that is, the awareness of how the choices of certain visual images of conflicts and their associated languages could bear implications for the making of a community and the "dynamics of collective belonging" [5: 520-1].

As valid as Chouliaraki's arguments are, it must also be stated that the intrinsic characteristic of these citizenship visual reportage, as narratives of witnessing, is not anchored on their symbolization role alone, but also on the value of the citizen bystanders 'being there' on the ground. A number of scholars [1], [2], [6], have placed strong emphasis on this 'eye witnessing' aspect of the practice. Studies [1], [6], further confirm that it is precisely this eye witnessing imperative that could, in the main, be drawn upon to negotiate conceptually the distinctions between amateur images (that are subjective and offer, in real time, distressing insights into events of tragic nature) and the more professionally made images meant for relaying hard facts [1].

Though newsworthy in all cases and reflective of other values, it is worth noting that the way and manner by which the 'raw' scenes of the events in Badagry and Lagos Island are foregrounded in the two sets of the inter-related videos seriously breach the principles of 'good taste and decency' in the display of images of the suffering and death of others. The need to protect the public from any emotional traumas that could result from viewing these gruesome images of spectacles has always been at the baseline of the good taste and decency policy [5].

The representations, in their 'raw' states, of the continuous brutal cutting of the 19-year old boy with a machete in Lagos Island and the repeated stoning of the 16 year old boy in Badagry to make him unconscious are seriously offensive and disturbing. While the visual depictions of these spectacles in their raw states reveal what truly happened at the scenes as well as the evil tendencies of the perpetrators of these crimes, these 'raw' depictions of social realities does not show the citizen photojournalists' sensitivity to the emotional shock that could possibly result from watching them.

Yet, drawing insight from Chouliaraki's [5: 522] tripartite regulatory regimes - the economy of taste and decency (i.e. the ethical standard which bans the display 
of the imagery of suffering and death on screen in response to public's aversion to atrocity); the economy of 'display' of gruesome images (i.e. the subtle approvals and the denunciatory language displaced as accompaniments to the images of atrocities); and the economy of 'witnessing' (i.e. "an economy that controls the boundaries of taste and decency and the linguistic practices of display in ways that are politically, rather than morally or aesthetically, motivated") - in relation to visual videography, the only defence for such breaches of expected journalistic standards by the citizens photojournalists, as is often the case in other videos of conflicts and traumas, is the imperative of mediatory witnessing and testimony.

It is the economy of witnessing, with its central drive towards advocacy and to prove the authenticity of the reported events that could be drawn upon to balance out the ethical limits inherent in the foregrounding and display of these events in their 'raw' states. While this paper disapproves of the resulting ethical breaches, it does however accept that the validity of such breaches be grounded on nothing other than the need to seek quick interventions or mediations in favour of would-be victims of similar events in the future. In this regard, the central values of the 'raw' images of the gruesome murders of the two boys in Badagry and Lagos Island, respectively, may be more meaningfully placed, not merely against their aesthetical and moral regimes, but more so against their testimonial and mediatory regulatory regimes.

\section{B. Technological Structure and Care for the Victims}

How the mobile technological structure enables and/or impede the exercise of moral agency by the citizen visual reporters, in terms of care for the victims of the atrocious events, was tested by identifying the type of recording device used; the nature of the recording process; the presence of care for the victims; the presence of security operatives; the environment of the crime; the voice of plea of the victims; and the mood of the perpetrators in response to the plea.

Visual evidence suggests that the recordings of the spectacles were all made with mobile devices; possibly mobile phones. But it is not clear from all the videos the mobile phone types with which the footages were made. Evidence of lack of clarity of the mobile device types is high. Studies [7], [8], however, show that mobile phones and their accompanying recording devices have become a taken-for-granted part of contemporary Nigeria society.

While the first sets of mobile phones emerged in Africa in the 1980s, the Nigerian government introduced mobile phones into the country as late as 1990s. However, mobile handset capable of doing a number of other functions outside voice calls and meant for average consumers gradually appeared only in 2002. By late 2005, mobile devices with different designs, functionalities, and affordability were fast becoming the norm. Adomi [8] admits that an increasing number of Nigerians are now taking advantage of the potentials of the mobile communication systems. Apart from increasing access to the use of telephone services, it has brought about plurality in citizenship news coverage. In particular, their usages now make the management of personal photographic and video archives possible as well as the sharing of some of these visual images across global digital platforms.

The prioritization of technologies over and against the human factor has, however, remained a point of critical consideration in scholarship, with the increasing distancing of the debates from the trappings of technological determinism [9], [10]. The pull of the debates has changed to an increasing recognition that technologies by themselves are inert. Their power to communicate and enable change through witnessing is rooted in the way they have been taken up by users. This paper agrees with this scholarly position.

Thus, if anything meaningful is be understood about the structural and witnessing potential of the mobile devices used in the recording of the atrocious events, that understanding should be driven the concept of interdependence between the technological and a plethora of human factors, such as human social cultures, human vision and imagination [11].

In this respect, the enabling and impeding qualities of the mobile technologies, used in the recording of the events in Badagry and Lagos Island, cannot be tied with the technology alone. The human judgements, the ways the frames are made, how the shots assist the sociopolitical movement of the time, competencies and other factors that impinged on the uses of the technologies, also count.

Cammaerts's [12] exploration of "technologies of selfmediation", for example, offers other significant perspective for connecting the values of the mobile technologies with citizenship visual witnessing. His specific emphasis is on the "affordances" and "constraints" of these media types.

The enabling potentials include disclosure (the manners in which image frames are produced and disseminated), examination (self-reflexivity and how the shots assist the coordination of the socio-political movement), and remembrance ("the ways in which movement frames and protest tactics are recorded and archived, potentially leading to movement spill-over"). The impeding elements, in contrast, are tied around the issues of "access" to the technologies and news contents and the "technical skills" in relation to their usages (e.g. production competencies of citizen reporters and the 'reading' skill of audiences). The significance of these factors must, however, be evaluated both at the point of production and reception [12].

These specificities are particularly useful for understanding how the communication abilities of the mobile devices used in recording the events in LagosNigeria could be seen to enable or impede the moral 
agency of the citizen photojournalists in relation to the narratives of the killing of the two boys. Again, while the problematic of "access" are now more than ever tied around the availability of technological innovations, telecommunication services, government's regulatory policies, as well as the willingness of mainstream media to report on the frames from citizen reporters, "competency" is not regarded as a prerogative of citizenship visual practice; it is only a defining quality of professionalism [13]; [19]; 20].

The unprofessional nature of the videography is clearly self-evident in all the visual cases from Lagos: the camera movements are generally unsteady; the shots, too, are very shaky in response to the quick swings of the mobile phones. The shots are also lacking in camera angle variations. Most of the shots are wide angle, long shots. There are some close-up and extreme close-up attempts in relation to the Badagry scenario. But only a few times do the cameraman attempts close-ups (definitely not extreme close-ups) in relation to the Lagos Island conflict; thus, making it difficult for viewers to see at very close range the expression of pains and tears on the face of the 19-year old boy as his body is repeatedly cut with machetes.

These technical elements clearly illustrative of the human elements and/or the unprofessional approaches associated with the making of these visuals. The lack of the expected technical skills in relation to the productions of these visuals, to a great extent, is illustrative of the experimental nature of the production processes themselves, which is often at the heart of citizenship amateurish videography.

However, the potential of these footages in assisting the sociopolitical movement of the time is very much tied with the wrongful assumption that jungle justice could assist in the protection of local communities against the spread of violent crimes. This ideological reality is, however, not self-evident in any of the videos but can only be inferred as part of the self-reflexivity of their viewers.

Again, evidence from the videos shows that care for the victims of the atrocities was absolutely lacking. There is no presence of the personnel of any of the security agencies. The foci of the bystander-videographers are explicitly on the events before them, not the need to rescue the victims. The only evidence of care is the lone voice of an elderly figure in some of the videos pleading for the life of the victims to be spared. For example, an elderly person, dressed in a white flowing gown, is seen in the first Lagos Island video trying to intervene; but was pushed aside and stones hauled on the head of the 19-year old victim who then lay still.

Duty of care is a universal principle. This principle is also implicated in the ways technologies are used. That an individual may owe a duty of care to another to ensure that they do not suffer any unreasonable harm or loss is particularly a central requirement of divine revelation, moral philosophy, and even legal policies.

For example, the Aristotelian ethical tradition, which is substantially grounded on the evaluation of human character and virtue, upholds that having a virtuous inner disposition will also involve being moved to act in accordance with that disposition [14]. Realizing, for example, that care is the appropriate response to a situation and feeling appropriately disposed towards caring will also lead to a corresponding act of kindness towards others.

Also, the Nigerian legal systems [15], with their roots in acceptable philosophical principles and the English legal systems, in some areas, absorbed and expressed the requirement to care for all, particularly victims of potential crimes and civil offences. While the Constitution, on the one breath, places the duty of care towards all citizens in the hands of government (article $14.2 \mathrm{~b}$ ), it recognizes, on the other breath, the sovereign right and power of the citizens to shape how government exercises this duty in a participatory manner (article 14.2a and 14.2c). This oscillation between government and the citizens is a significant recognition of the kind of collaboration necessary for the actualization of the principle of care in its broadest sense.

This sense of care is absolutely lacking in the videos about the treatment of the two young boys. Lack of care is further proved by the very uses of the mobile technologies themselves as well as the responses of the perpetrators to the 'voice' of plea by the victims. The uses of the technologies in both the Badagry and Lagos Island events are not in connection with voice calls or even SMSs to seek out help for the victims of the atrocities. Rather the uses are tied around visual image generations to bear witness to the atrocities.

While the visual images themselves are iconic, at least for forensic purpose, the lack of specific focus on voice calls or even SMS could be taken as indicative of a possible presence of an unresolved moral dilemma in the judgement of the citizen-witnesses themselves. The citizen photojournalists appear themselves caught up in the heat of the crowd's passion.

Also, in all the videos, there is no evidence of victim's explicit affirmation of committing a crime. However, a 'voice' of plea for mercy and pardon is moderately evident in the two videos about the Badagry spectacle. A speech conveyed through 'pleading-silence' is not completely absent either. In the Badagry videos, when speech eluded the boy, he mimed for clemency with the wave of a hand. This is foregrounded against the strong voice of assertions, anger and promise of extermination of the victim by the crowd: "Your life will end today" (said in Yoruba); "Knack-am well" (said in Pidgin); "Bring the fuel" (said in Yoruba).

The voice of the victim of the Lagos Island fighting is completely muted, perhaps due to the distance of the mobile device from the spot of the mutilation. But the 
voice of the perpetrators, which also provides tints of their moods and intention, is highly audible.

Apart from the materiality of 'voice' in enabling one (community or individual) give an account of himself, voice can also become expressive of a distinctive political perspective of an imagined community that needs to be addressed, particularly a community with entrenched structures of inequality and legal breaches. Seen from these perspectives, this paper agrees with Couldry's [16] position that 'voice', expressed through the instrumentality of citizenship media, is not just a political tool but can also become a force for overcoming the dominance of violence in a community and for bringing about a radical behavioural and cultural transformation within that community. In this regard, the verbal and non-verbal gestures of plea by the victims could be taken to speak in favour of greater need for empathy towards the victims of atrocious events in local communities, even when there is the burning need to redeem such communities from the stench of criminality.

While the overall intention of the perpetrators is to rid the community of crimes, the killing of these young boys is generally lacking in ethical value. This position is more specifically captured in the accompanying text commentaries which either denounce as evil or approve as good the crowd's actions against the victims. There is also an evidence of neutral ethical positioning. For example, out of the 47 commentaries that accompanied the Badagry spectacle (35 for first video and 12 for second video), a total of two are in affirmation of the atrocious events; 37 disapprove of them; only eight are neutral. While the affirmation frequency is medium, the denunciation range is high.

This is a sign that majority in the community do not support such unethical conducts against any victim. It is also a statement of the ethical position of the broader global community against jungle justice. Chouliaraki [5], for example, argues that the foregrounding of such subtle approvals or denunciations of barbarism displayed as linguistic accompaniments to visual images, is valuable as an ethical strategy in journalism for managing people's unique mode of encounter with distant but potentially traumatic events.

In view of these findings, what then is the connection between the mobile technologies used and the moral agency of the citizen-witnesses? The technologies as enablers have assisted, for example, in capturing the 'voices' of the victims challenging the community to a growing sense of pardon. The citizen reporters have also found their 'voice' through the recording of the misery and suffering of the victims, the contents of which could become catalysts for social actions. Evidence of the impeding factor lies more in the unprofessional ways the videos were made.

Other enabling or impeding factors are external to the mobile devices. They are directly tied with the perception of the actions (or inactions) of the victims by the bystander-participants, as well as their 'hypothetical' conception of the state of the local communities. The technologies could also become enablers if their previously recorded contents either become motivating forces for future infringements on the rights of other citizens accused to have committed similar crimes or serve as catalysts to secure care for would-be victims or help local communities seek out and adopt new values that are ethically acceptable in their attempt to secure a crime-free society.

\section{The Ethical Tragedy in Citizenship Visual Practice}

Identifying what constitutes the ethical tragedy in the citizenship visual practice and locating where the tragedy resides are based on this paper's hypothetical assumption that there is a level of hypocrisy in the practice of citizenship visual reporting in contemporary times. The answers are sought, not only from within the videos themselves, but also from outside the footages through oral conversations.

Though the word 'tragedy' is often used to represent a very sad (if not fatal) situation, it is taken within the context of this paper to refer to the shocking condition whereby citizenship visual practice is increasingly being valued primarily in terms of its news values and less for its inherent humane requirement.

From the visual perspective, none of the videos confirm the presence of security personnel or any attempt by the bystanders to seek out police help to protect the lives of the victims. In this regard, there is a clear evidence of a serious negligence of the requisite duty of care towards victims of tragic public situations by the bystander-participants. This negligent tendency, because it undermines (consciously or unconsciously) some of the core values of citizenship reporting (such as empathy, the protection of citizens from harm, and modelling citizenship), it is argued, could also function to reveal the hypocrisy underlying citizenship photojournalistic practice today.

Outside the visual contents, the occasional flawed nature of the techniques involved in the formation processes of these visuals, though often overlooked as consistent with amateur videographic practice, could also be viewed as tragic, especially when the visual claims made are carefully manipulated to tell only one side of the story, neglecting the side that could have favoured a more sympathetic association of viewers with the wrongful persecutions or destructions of victims of alleged crimes.

From oral interviews, respondents disagree as to whether the contradiction involved in citizenship visual practices is tragic. Those that see it as tragic are of the view that, normally, the citizen reporter would be expected to do his or her work generating stories and the neighbours who also witness the events to do theirs. It is, therefore, not advisable for a reporter to put himself in a harm's way by attempting to intervene directly on behalf 
of a victim of public attacks, to avoid becoming a victim himself. That is because the ability of the perpetrators to engage in any logical thinking is always very low in a moment like that. Those who see the situation as not tragic admit that most citizen reporters who report on such events do actually fulfil a moral responsibility that is tied around their duty to inform the public about such events. In this regard, they cannot be held to be negligent even when their passion is first directed towards news reporting alone.

Other interviewees, in contrast, maintain that "the whole situation" of reporting on atrocity is tragic. The tragedy is not only in relation to the activity of the citizen reporter, it relates also to the action of the perpetrators. In fact, "it is the tragedy of humanity", which is tied around a number of indices, including the image of the local communities that tolerate such barbaric activities and the loss of life often involved in such events. The action of the citizen reporters, though done at the spur of the moment, becomes tragic when their coverage of the events does not roll out enough facts to inform the public that what had taken place was tragic and should never be allowed to happen again. These interviewees argue that "as a people, we are very much sensitized to see and believe that some of the public killings of innocent citizens are necessary. People have come to accept them as normal. This is tragic. The news reports themselves do not always raise the level of anger necessary for the larger population to react against these atrocious events. This too is tragic because it allows impunity to continue".

All the respondents, however, acknowledge that there is always a dilemma inherent in the practice and which needs to be resolved on the spot. They argue that the first instinct of any photojournalist is to generate a story in order to let people know what is happening. Often, there is little consideration of how help could be sought for the $\operatorname{victim}(\mathrm{s})$. They maintain that it is the positioning of the reporter in relation to this social function that often determines his response type.

The view of respondents and footage evidence notwithstanding, the tragic, it is argued, resides both within and outside the practice of citizenship reporting itself. And because they breach some basic ethical expectations that are grounded on the principles of care and compassion, the contradictory tendencies in citizenship visual reportage, should be seen to constitute an ethical tragedy for the practice and requires public criticism, that is, if change must be brought to bear on the practice at all levels: ideological, political, and pragmatic.

\section{Duty of Care and the Drive to Bare Witness}

How citizens who use mobile technologies could reconcile the duty of care for victims of tragic public incidences and the immediate concern to capture and represent events in ways that are fresh and immediate was tested from conversational and argumentative points of view. The interviewees all recognize the complexity (emotional and situational) involved in recording any public atrocious events. For them, it is the nature of the event or the situation the citizen reporter finds himself or herself that, to a great extent, determines his or her line of action. The interviewees maintain that ability to reconcile the two duties - the duty to care and to report events would depend largely on what the citizen reporter sees on the ground.

It might not even be possible for a citizen reporter to talk and calm down an angry mob. In some cases, rushing in to record an atrocious event might not even be wise, as the mobile camera could be seized and destroyed by the mob. In other cases, the reporter could help by finding a way to connect with nearby mainstream media houses or security agencies to intervene. But generally, there is always a $40-30 \%$ chance that even if a call is put across the victim would be rescued, as the mob reaction is always very swift and not properly thought through. But where it is a case of a motor accident, for instance, it would be easier to know what to do first - help rescue the victims and then photograph the event later or do both simultaneously. But outside this, interviewees argue, it might be difficult to know what to do first. Where one is dealing with a mob reaction that could become volatile the response would always have to be personal.

One interviewee's response was tied to the way news contents are ordered. Citizen reporters, he argues, should work to balance their stories to bring out, not just the objectivity, but more importantly the moral aspect. In other words, their news contents should be ordered to sensitize us on the values that are dear to our common humanity, such as respect for human life. Non-adoption of recognized legal procedures should be made to be seen as unacceptable. Another respondent argues that "citizen reporters need to exercise restraints in the kind of pictures they put out for public consumption, to avoid institutionalizing what ordinarily is condemnable. Again, when dealing with online media that is populated by people who have little consideration for ethics, what are important are our individual moral dispositions and our general attitude as a people that could work to reduce impunity in the way we handle issues involving human life".

All said, it is the position of this paper that witnessing to trauma through the foregrounding of spectacles so as to mediate in them is a worthy objective. It is an expression of the social responsibility of every citizen. But equally significant is the need for witnesses to position themselves, first and foremost, as people with a responsibility to love others (including those suspected to have committed crimes) and to preserve life. While the confused state of the bystander-participants in a scene of public strive itself could create difficulties in making quick choices as to what to do first in such moments whether to call for a rescue or to document the event or to challenge the injustices verbally -, it is generally the failures of the citizen witnesses at 'conflation' in relation 
to their expected positions and roles that might, perhaps, offer the tipping line for locating where the dilemma and the tragic in citizenship visual reporting sometimes resides.

The avoidance of this tragedy, it is argued, rests more significantly on the willingness of the bystanderwitnesses to do the needful in terms of carefully balancing their social responsibility expectation when recording atrocious events with the need to care for the victims of such events. When evaluated, therefore, from the points of view of the requirements of divine revelation, moral philosophies and of legal prescriptions outlined above, careful balancing between the responsibility to bear witness through reportage and the need to protect life appears to be the necessary pragmatic path to follow by every reasonable person.

Thus, beyond the broader applicability of the doctrine of care within the business and medical worlds [17], [18], [19], it is important for all privatized practitioners to understand that they also owe a duty of care to their fellow citizens. Citizen photojournalists, in particular, would need to accept that they, too, cannot just wash their hands off it and say they have no duty of care. To do so will amount to serious act of negligence. Building the awareness and making a conscious decision to be doubly responsible could help citizen videographers in bypassing the dilemma sometimes inherent in the practice, as well as help in reducing the tragic implications indifferent attitudes and behaviours could bear on the integrity of citizenship photojournalism itself.

\section{CONCLUSION}

The study focused on citizens' uses of mobile technologies in reporting atrocious social events and the ethical tragedy that arises in the course of that practice, caused by unresolved dilemmas or indifference on the parts of the citizen-participants. Additionally, the paper sought to understand the cultural activity that define the moral agency of citizen photojournalists, the functionality (enabling or impeding imperatives) of mobile devices in relation to the moral agency of every citizen videographer, as well as how citizen photojournalists could reconcile the requisite moral duty of care with the need to video and represent tragic public events.

While findings in relation to the issues were specific to the Nigerian experience, replete of similar problematic situations could be found across a number of other countries, making the research problem a universal problem that requires global research responses. Findings reveal, firstly, that while witnessing in and through the media is at the heart of the moral agency of the citizen photojournalists at the moment of the tragic events, mediation through information provision and activism for the purpose of practical reforms remains the ultimate objective. While the ethical imperative of journalistic visual representation of spectacles require that photojournalists exercise reasonable care in displaying such images to avoid offending people's taste and decency, evidence also suggest that 'raw' images of the events were displayed without much regard for their possible emotional impacts on viewers and that these 'raw' visual images could function, regardless of the regulatory breaches, to elicit intervention in favour of victims of the conflicts.

Secondly, mobile technology by itself is inert. The enabling or impeding functionalities of the technologies are tied more directly with the manner of usages of these technologies by citizen photojournalists and with other human factors such as imagination and subjective viewpoints. Directly, the technology has provided 'voice' for the victims, the perpetrators and the citizen reporters enabling social actions for change. The only context within which the technologies could be seen to have an indirect enabling impact on the moral agency of the citizen visual reporters is where their recorded contents could become catalysts for future infringements on people's rights by other young adults under the guise of jungle justice.

Thirdly, the tragic in relation to the moral agency of citizen photojournalists could be tied directly with the inability of the citizen reporters to reconcile, at the spur of the moment, the demands of their social responsibility contract (exercised through the visual reporting of atrocious events considered as news worthy) and the religio-legal-moral requirements to protect life and to seek out care for victims of atrocious social events, using the voice call or SMS capability of their mobile devices.

The duty of care the practice of citizen videography requires towards victims of tragic events and the 'sites' of the moral dilemmas sometimes faced by those who report these events have been logically argued in this paper. The 'tragic', it is argued, is in the negligent tendencies of the citizen visual reporters, manifested in the increasing loss of empathy towards the victims and the confusion often encountered by bystanderparticipants in deciding which role ought to be predominant: the recording of the events or the seeking for rescue for the victims. This negligent tendency is well documented in the two sets of videos from Badagry and Lagos Island and other instances. In all cases, putting out a quick voice call or SMS to security operatives was neglected by the citizen-reporters, while the desire to visually record the horrible events took greater hold.

This approach to reporting, it is argued, constitutes nothing but a tragedy to citizenship photojournalism. It is 'tragic' for the people's journalism whose core values have been underlined, not only by the ethical values of objectivity and neutrality or the aesthetics of empirical truthfulness, but more so by empathetic and moral considerations. These are some of the key values that could be realized when the logic of care is given prime importance in the practice.

The question begging for answer is: How do we make sense of this development, reconciling it with the central 
values of citizenship reportage? How can this inherent dilemma be avoided (if not entirely eliminated) in the future? The position of this paper is very clear. There must be a conscious, reasonable and careful balancing between the call to social responsibility through media witnessing and the prerequisite moral duty to care for and protect the lives of victims of traumatic events. The acceptance of this demand must, however, go beyond the mere imperatives of sociocultural regulations or policy formulations [20], to the internalization of sets of acceptable moral values [19] or a conscious actualization of the Aristotelian ethical dictum - act in every situation as any virtuous man should [14].

While we need citizen reporters to spontaneously generate newsworthy stories, we also need, above all else, those whose sense of moral responsibility in the alternative journalistic field is limitless. The adoption of this alternative approach could, at the long run, help minimize brutal killings resulting from jungle justices as well as open up broader social spaces for the needed legal processes to take their reasonable courses, in response to any kind of crime or social upheaval committed within our communities.

\section{ACKNOWLEDGEMENT}

The authors wish to thank the Chancellor and the management of Covenant University, Nigeria. This work was supported in part by a grant from the academic research poll of the university.

\section{REFERENCES}

[1] A. Stout, Citizen Witnessing: Revisioning Journalism in Times of Crisis, Cambridge, UK: Polity, 2013

[2] F. Paul and P. Amit, eds., Media Witnessing: Testimony in the Age of Mass Communication, UK: Palgrave Macmillan, 2009

[3] A. Stout, S. Prasun, and C. Cynthia, "Bearing witness: Citizen journalism and human rights issues," Globalisation, Societies and Education, vol. 5, no. 3, pp. 373-389, 2007.

[4] T. John and B. R. Warwick, "Iconic photojournalism and absent images: Democratization and memories of terror," in Routledge Companion to News and Journalism, S. Alan ed., London \& New York: Routledge, 2010, pp. 507-519

[5] C. Lilie, "Journalism and the visual politics of war and Conflict," in Routledge Companion to News and Journalism, S. Alan, ed., London \& New York: Routledge, 2010, pp. 520-531

[6] Z. Barbie, "Photography, journalism, and trauma," in Journalism After September, B. Zelizer and S. Allan, eds., London \& New York: Routledge, 2002, pp. 48-68

[7] W. Oscar, Mobile News: A review and model of journalism in an age of mobile media, In Digital Journalism, UK: Routledge, 2013, pp. 6-26

[8] A. E. Esharenana, "Mobile Phone Usage Patterns of Library and Information Science Students at Delta State University, Abraka, Nigeria," Electronic Journal of Academic and Special Librarianship, vol. 7, no. 1, 2006.
[9] M. Marshal, The Gutenberg Galaxy: the Making of Typographic Man, Toronto \& London: University of Toronto Press, 1962 (2010 reprint)

[10] W. Raymond, Television, Technology and Cultural Forms, Third Edition, London \& New York: Routledge, 1990

[11] T. Sebastian, Mobile Evolution: Insights on Connectivity and Service, Boca Raton, NW: CRC, 2015

[12] C. Bart, "Movement media as technologies of selfmediation," in Routledge Companion to Alternative and Community Media, C. Atton ed., London \& New York: Routledge, 2015, pp. 445-456

[13] A. Chris, Alternative Media, Los Angeles, London, New Delhi \& Singapore: SAGE, 2002 (2008 reprint).

[14] M. Richard (ed.), "Nicomachean Ethics (NE)," in Introduction to Aristotle, New York: McGraw Hill, 1947, pp. 308-543

[15] Constitution of the Federal Republic of Nigeria 1999 [Online], Available at: http://www.icnl.org/research/library/files/Nigeria/constituti on2.pdf

[16] C. Nick, "Alternative media and voice," in Routledge Companion to Alternative and Community Media, C. Atton, ed., London \& New York: Routledge, 2015, pp. 4353

[17] O. Nelson, O. Kehinde, O. Olusola, O. Rotimi, and S. E. Olukoya, "Effective use of information sources for breast cancer care: Interplay of mass media and interpersonal channels. Creating global competitive economies," in Proc. 22nd International Business Information Management Association Conference, 2013.

[18] O. Oscar, O. Oladokun, O. Nelson, and E. Thelma, "Sobotone, ponkiriyon, herbal marketing communication and Nigeria's Healthcare system," in Proc. Socioint, Dubai, UAE, 2017.

[19] O. Patrick, "Rethinking media policy in anglophone subSaharan Africa: The challenge of community media," Media Watch, Journal of Communication, Journalism and Media, vol. 8, no. 2, pp. 270-286, May 2017.

[20] O. Patrick, "Changes in media policy in Sub-Saharan Africa: The role of community media." Ph.D. dissertation, Department of Creative Industries, Edinburgh Napier University, Edinburgh, Scotland, 2014.

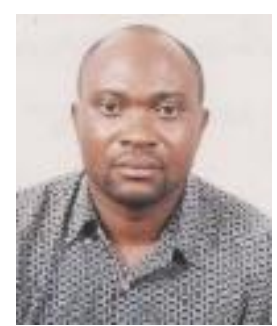

Patrick E. Okon is a lecturer in the Department of Mass Communication of Covenant University, Nigeria. He holds a Ph.D. in media policy and alternative journalism interface from the Edinburgh Napier University (Scotland), M. A. in Pastoral Communication from the University of Calabar (Nigeria), and M.Litt in Film Studies from the University of St. Andrews (Scotland). His research interests include media and society (policy and alternative media interface), development communication, broadcast journalism, media and religion interface, and film studies (theories and criticism). 


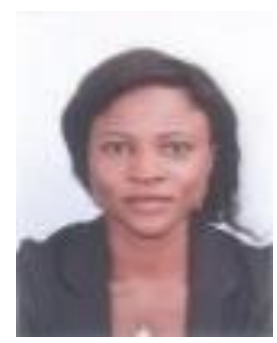

Tolulope Kayode-Adedeji is an assistant lecturer in the Department of Mass Communication of Covenant University, Nigeria. She obtained M.Sc in Contemporary Media from the University of Wolverhampton, United Kingdom. She is currently a Ph.D. candidate at the Department of Mass Communication of Covenant University. Her research endeavours focus on violent conflict and internet communication interface, especially as it affects online security for children and adolescents.

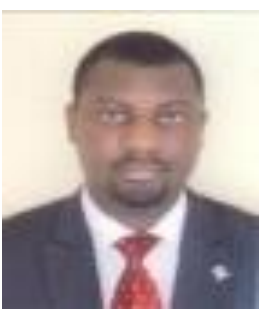

Lanre Amodu is a Senior Lecturer and the Head of the Department of Mass Communication of Covenant University, Nigeria. After B.A. in Performing Arts from the University of Ilorin (Nigeria), he proceeded to obtain his M.Sc and Ph.D in Public Relations from Covenant University (Nigeria). His research interest includes film studies, as well as public relations and advertising. 